\title{
Analysis of Shopping Consumer Preferences Online and Offline Stores in the Pandemic Time of Covid-19
}

\author{
Cut Nizma* \\ Department of Accounting \\ Politeknik Negeri Medan \\ Medan, Indonesia \\ *nizma@polmed.ac.id
}

\author{
Dina Arfianti Siregar \\ Department of Accounting \\ Politeknik Negeri Medan \\ Medan, Indonesia \\ dinasiregar@polmed.ac.id
}

\begin{abstract}
At the time of the Covid-19 pandemic, people were encouraged to stay at home to avoid Covid-19 transmission and shop online. However, in reality the traditional markets are still crowded with people to shop for their daily needs. This study tries to find answers to how consumer preferences for shopping at online stores and offline stores during the Covid-19 pandemic, what factors influence consumer preferences for shopping at online stores and offline stores during the pandemic, what factors most dominant influence consumer preferences for shopping at online shops and offline stores during the Covid-19 pandemic, and how the accuracy of the model predicts the probability of consumers choosing to shop online compared to offline shopping during the Covid-19 pandemic. The method used in this research is through stages starting with observation and survey, data collection, data analysis with descriptive statistics and Binary Logistic Regression analysis. The results showed the factors that influenced consumer preferences in shopping at online stores and offline stores during the Covid-19 pandemic were the ease of obtaining products and social experiences. The most dominant factor affecting consumer preferences for shopping at online and offline stores is the ease of getting products. For the best logit model in this study, the classification accuracy of the approach is quite high.
\end{abstract}

Keywords—consumer preferences, online stores, offline stores

\section{INTRODUCTION}

The pandemic virus of COVID-19 (Corona Virus) that is currently happening, requires people to stay at home. However, the community must still fulfil their daily needs. The existence of an online shopping system or online is very helpful for the community in fulfilling their daily needs, so that the government's appeal to stay at home can be obeyed. The online shopping system is a scripless business [1].

With the occurrence of the corona pandemic, the Indonesian people, consciously or unconsciously, have changed their shopping behaviour. Nielsen said that since the enactment of the call to stay at home, as many as $30 \%$ of consumers are more likely to shop online [2]. There was an $11.3 \%$ increase for online shopping, especially grocery items and also foodstuffs such as meat, vegetables, and fruit through applications during the Covid-19 pandemic, and the most widely used was applications e-commerce at $48.9 \%$ [3].

However, for products that are online shopping system services, it is still growing rapidly, but to shop for existing needs at retail stores, Indonesians prefer conventional shopping systems directly to kiosks or shops or supermarkets because there are five Indonesian people's behaviour in terms of shopping that are not easy to switch to online shopping, namely directly being able to watch the goods, try, taste and enjoy food and drinks between shopping, and bargain for products $(5 \mathrm{M})$ and these five things make Indonesians still need conventional or shopping offline until the future

A social observer during the Covid-19 period in North Sumatra the increase in the online shopping system has apparently not made traditional markets and supermarkets devoid of buyers, seen in several commercial markets in Medan the situation is still congested continue as if you don't know or don't hear about corona.

Consumers can use the two types of shopping differently. Some consumers may use shopping offline to buy basic necessities and use shopping online for additional needs and some are following the opposite pattern, especially during the current Covid-19 pandemic. As a result, the same consumer may show different preferences when shopping at online and stores offline.

Based on this background, the author wants to do research with the title: " Analysis of Shopping Consumer Preferences Online and Offline Stores in The Pandemic Time of Covid-19".

Formulation of this research problem is: what are the characteristics of consumers who shop at stores online and stores offline based on demographics (gender, age, education level, income level) during the Covid-19 pandemic? What factors influence consumer preferences for shopping at online and stores offline during the Covid-19 pandemic? What is the most dominant factor influencing consumer preference to shop at online and stores offline during the Covid-19 pandemic? How accurate is the model in predicting the probability of consumers choosing to shop online compared to shopping offline during the Covid-19 pandemic? 
objectives of this study are: to determine the characteristics of consumers who shop in stores online and stores offline based on demographics (gender, age, education level, income level) during the Covid-19 pandemic, to find out the factors that influence consumer preferences for shopping at online stores and stores offline during the Covid-19 pandemic, to find out the most dominant factors affecting consumers shopping at online stores and stores offline during the Covid-19 pandemic, to find out how much accuracy the model predicts the probability of consumers choosing online shopping compared to shop offline during the Covid-19 pandemic.

\section{LITERATURE REVIEW}

Consumers' preferences for various products and services are called consumer preferences and consumer preferences are formed from how consumers respond to these products $[4,5]$. Price is the value given to a product or service and is the result of a series of calculations, research and understanding and complex risk-taking capabilities. Product variations are different shapes made by factories [6]. Convenience is that it is not difficult to obtain goods or services. Products that are easy to obtain, do not take a long time to obtain, will lead to consumer satisfaction [7]. Quality is the ability of a product in terms of carrying out its functions, including how its level of durability, reliability, precision, easy implementation and repair, and other important and valuable attributes that exist in the product as a whole [8]. Family is a primary group that plays an important role in the socialization of its members towards product use behaviour [9]. Shopping systems are scripless businesses [1]. Shop offline is meeting directly between the seller and the buyer in one particular place to carry out buying and selling transactions of goods or services.

\section{A. Previous Research}

Conducted a study entitled online shopping behaviour in Indonesia. The results showed that there are several things that cause people to buy online, namely confidence in goods, price, convenience and ease of shopping, availability of goods, security, product quality, website design [10].

Conducted a study entitled Consumer Preference-A Comparative Analysis. The results found that online shops have several competitive advantages over traditional stores due to lower prices, easy information, convenient mechanisms for placing orders and payments, product variety, sufficient stock, options for consumers to choose. Offline stores also have a competitive advantage over online stores, namely the presence of physical inspection facilities, direct ownership, guaranteed delivery of the same products as specified, immediate satisfactory consumer demand, better after-sales service, better return policies and consumers have a social experience when shop [11].

\section{RESEARCH METHODS}

This research uses descriptive methods and quantitative analysis, with the data used are qualitative and quantitative data. This descriptive method is used to determine the characteristics of respondents regarding shopping preferences at stores online and stores offline during the Covid-19. The quantitative analysis method uses the Logistic Binary Regression model (logit model). This logit model is used to find out how much chance the respondent has to choose to shop at a store online. Sampling technique sample selection is done randomly sampling of consumers who have shopping experiences online and offline. The sample is determined to be 111 people who are still in the range of 30 to 500 [12], and data was collected by distributing questionnaires to respondents via google form. Research variables and measurement scale variables of this study consist of two variables, namely the dependent variable (Y), namely the consumer's decision to choose to shop at online and stores offline. The independent $\operatorname{variable}(\mathrm{X})$ is price, product variation, ease of getting the product, product quality, social or family experience. The questions for the independent variables are arranged by being given a score range using a scale Likert consisting of Strongly Agree (SS with a score of 5), Agree (S with a score of 4), Neutral (N with a score of 3), Disagree (TS with a score of 2), Strongly Disagree (STS with a score of 1). Validity and reliability tests were carried out to measure the research variable indicators by testing the items -the item of the question in the questionnaire.

\section{A. Data Analysis Techniques}

- Descriptive

- Analysis of Regression Binary Logistic

In this study the variables used to see consumer preferences for choosing to shop at online stores and stores offline are as follows:

$$
\operatorname{Ln}(\mathrm{p} / 1-\mathrm{pi})=\alpha+\beta 1 \mathrm{X} 1+\beta 2 \mathrm{X} 2+\beta 3 \mathrm{X} 3+\ldots+\beta \mathrm{XXk}
$$

Based on equation (1), the model to be built in predicting consumers in choosing to shop online and offline are as follows:

$\operatorname{Ln}(\mathrm{p} / 1-\mathrm{pi})=\alpha+\beta 1 \mathrm{H}+\beta 2 \mathrm{VP}+\beta 3 \mathrm{KP}+\beta 4 \mathrm{KLP}+\beta 5 \mathrm{PS}$

After the logit model is found, the model is tested using the following tests:

1) Model significance test: To determine the effect of independent variables on dependent variables simultaneously (simultaneously / overall) in the model, you can use the test likelihood ratio, the hypothesis is as follows:

$\mathrm{H} 0: \beta 1=\beta 2=\ldots=\beta p=0$

There is no influence of independent variables simultaneously on dependent variables. 


\section{$\mathrm{H} 1$ : there is at least one $\beta \mathrm{j} \# 0$}

There is an effect of at least one independent variable on dependent variables.

The Formula:

$\mathrm{G} 2=-2 \ln +[\mathrm{lo} / \mathrm{lp}]$

2) Wald test: This test is done to see significant level of each parameter can be done through the Wald test, where the Wald test hypothesis is as follows:

$\mathrm{H} 0: \beta 1=0$

The independent variable $\mathrm{j}$ does not have a significant effect on the dependent variable

$$
\mathrm{H} 1: \beta \mathrm{j} \# 0
$$

The independent variable $\mathrm{j}$ has a significant influence on the dependent variable.

For a particular $\mathrm{j}: \mathrm{j}=0,1,2, \ldots \mathrm{p}$

The test statistics Formula is:

$\mathrm{Wj}=[\beta \mathrm{j} / \mathrm{SE}(\beta \mathrm{j})] 2 ; \mathrm{j}=0,1,2, \ldots, \mathrm{p}$
This statistic has Chi Square distribution with degrees of freedom 1 or $\mathrm{Wj} \sim \mathrm{X} 2$ where $\mathrm{H} 0$ is rejected if $\mathrm{Wj}>\mathrm{X} 2 \alpha, 1$. If $\mathrm{HO}$ is rejected, it means that the parameter is statistically significant at the $\alpha$ level of significance.

3) Reduction model test: In this test will be compared between the full model and the reduction model which only consists of parameters that are individually significant are:

$$
\mathrm{G}=-2 \operatorname{Ln}[\mathrm{LR} / \mathrm{Lp}]
$$

Hypothesis:

$\mathrm{H} 0$ is rejected if $\mathrm{G}>\mathrm{X} \alpha, \mathrm{pq}$, meaning that the parameters that are not found in the model are significant. Thus, the reduced variables need to be put back into the model so that a full model is formed. Meanwhile, if $\mathrm{H} 0$ is not rejected, it indicates that $\beta$ is not significant or all equal to zero.

\section{RESULTS AND OUTCOMES}

\section{A. Research Results}

\section{1) Data collection results}

a) Characteristics of respondents: The result from characteristics of Respondents show at Table 1.

\begin{tabular}{|c|c|c|c|c|c|c|}
\hline \multirow{3}{*}{ Characteristics } & \multicolumn{4}{|c|}{ Type of Consumer } & \multirow{2}{*}{\multicolumn{2}{|c|}{ Total }} \\
\hline & \multicolumn{2}{|c|}{ Offline } & \multicolumn{2}{|c|}{ Online } & & \\
\hline & $n$ & $\%$ & $n$ & $\%$ & $n$ & $\%$ \\
\hline \multicolumn{7}{|l|}{ Gender } \\
\hline \multirow{2}{*}{$\begin{array}{l}\text { Female } \\
\text { Male }\end{array}$} & 18 & 20.9 & 68 & 79.1 & 86 & 100.0 \\
\hline & 3 & 12.0 & 22 & 88.0 & 25 & 100.0 \\
\hline Total & 21 & 18.9 & 90 & 81.1 & 111 & \begin{tabular}{l|l}
1 & 100.0 \\
\end{tabular} \\
\hline \multicolumn{7}{|l|}{ Age } \\
\hline \multirow{3}{*}{$\begin{array}{l}<20 \text { Years } \\
20-45 \text { Years } \\
>45 \text { Years }\end{array}$} & 4 & 50.0 & 4 & 50.0 & 8 & 100.0 \\
\hline & 13 & 15.9 & 69 & 84.1 & 82 & 100.0 \\
\hline & 4 & 19,0 & 17 & 81.0 & 21 & 100.0 \\
\hline Total & 21 & 18.9 & 90 & 81.1 & 111 & $1 \quad 100.0$ \\
\hline \multicolumn{7}{|l|}{ Education Level } \\
\hline \multirow{5}{*}{\begin{tabular}{|l} 
Equal High Scho \\
Diploma \\
Bachelor \\
Master \\
Doctor
\end{tabular}} & 2 & 33.3 & 4 & 66,7 & 6 & 100.0 \\
\hline & 3 & 21,4 & 11 & 78,6 & 14 & 100.0 \\
\hline & 11 & 18.6 & 48 & 81.4 & 59 & 100.0 \\
\hline & 5 & 18.5 & 22 & 81.5 & 27 & 100.0 \\
\hline & 0 & 0.0 & 5 & 100.0 & 5 & 100.0 \\
\hline Total & 21 & 18.9 & 90 & 81.1 & 111 & \begin{tabular}{l|l}
100.0 \\
\end{tabular} \\
\hline \multicolumn{7}{|l|}{ Type of Occupation } \\
\hline \multirow{5}{*}{\begin{tabular}{|l} 
Housewife \\
Student / Student \\
Private \\
Employee Civil Servant \\
Entrepreneur
\end{tabular}} & 4 & 13.8 & 25 & 86.2 & 29 & 100.0 \\
\hline & 7 & 43.8 & 9 & 56.2 & 16 & 100.0 \\
\hline & 3 & 13.0 & 20 & 87.0 & 23 & 100.0 \\
\hline & 6 & 14.6 & 35 & 85.4 & 41 & 100.0 \\
\hline & 1 & 50.0 & 1 & 50.0 & 2 & 100.0 \\
\hline Total & 21 & 18.9 & 90 & 81.1 & 111 & 100.0 \\
\hline \multicolumn{7}{|l|}{ Income } \\
\hline \multirow{5}{*}{$\begin{array}{l}\text { <Rp. } 3,000,000 \\
\text { Rp. } 3,000,000-\text { Rp. } 6,000,000 \\
\text { Rp. } 6,000,001-\text { Rp. } 9,000,000 \\
\text { Rp. } 9,000,001-\text { Rp. } 12,000,000 \\
>12,000,000\end{array}$} & 9 & 24.3 & 28 & 75.7 & 37 & 100.0 \\
\hline & 6 & 18.2 & 27 & 81.8 & 33 & 100.0 \\
\hline & 5 & 25.0 & 15 & 75.0 & 20 & 100.0 \\
\hline & 0 & 0 & 13 & 100.0 & 13 & 100.0 \\
\hline & 1 & 12.5 & 7 & 87.5 & 8 & 100.0 \\
\hline Total & 21 & 18.9 & 90 & 81.1 & 111 & 100.0 \\
\hline
\end{tabular}

TABLE I. CONSUMER CHARACTERISTICS BY TYPE OF CONSUMER 


\section{B. Overall Model Fit}

The Overall Model Fit test or the whole model test is to test the independent variables in logistic regression simultaneously or simultaneously to influence the dependent variable. The overall model fit test is calculated from the difference in the $2 \mathrm{LL}$ value between the models consisting only of constants and the estimated model consisting of constants and independents. The -2LL test follows a chi square distribution with degrees of freedom.

TABLE II. TEST RESULT -2 LIKELIHOOD

\begin{tabular}{|l|l|l|l|}
\hline \multicolumn{2}{|c|}{ Value -2 Likelihood } & \multicolumn{1}{|c|}{$\begin{array}{c}\text { Value Chi } \\
\text { Square }\end{array}$} & p value \\
\hline $\begin{array}{l}\text { Constants } \\
\text { Constants }+ \text { Dependent } \\
\text { Variables }\end{array}$ & $\begin{array}{l}107,680 \\
94,480\end{array}$ & 13,200 & 0,022 \\
& & & \\
\hline
\end{tabular}

Based on Table 2 shows the value of -2 log likelihood which consists of constants only, and constants added by independent variables. The $-2 \mathrm{log}$ likelihood value that only includes constants is 107.680. Meanwhile, the -2 log likelihood value that includes constants and independent variables is 94.480. The comparison of the two log values likelihood is 13.2. Furthermore, the Sig. The model is 0.022 because this value is less than $5 \%$, it can be concluded that the variable product price, product variation, ease of purchase, product quality and social experience about the product simultaneously affect consumer preferences. Hypothesis testing in this study was carried out simultaneously by using the overall model fit test.

\section{Test of the Coefficient of Determination}

The coefficient of determination is used to determine how much variability of the dependent variable. The coefficient of determination in the logistic regression can be seen in the Negelkerke R Square. The value of Negelkerke R Square can be seen in the Table 3 below:

TABLE III. THE RESUlTS OF THE COEFFICIENT OF DETERMINATION

\begin{tabular}{|c|l|l|l|}
\hline Step & $\begin{array}{c}\text {-2 Log } \\
\text { Likelihood }\end{array}$ & $\begin{array}{c}\text { Cox \& Snell R } \\
\text { Square }\end{array}$ & Nagelkerke R Square \\
\hline 1 & 94,480 & 0.112 & 0.181 \\
\hline
\end{tabular}

The value of the coefficient of determination in the logistic regression model is shown by the Nagelkerke $\mathrm{R}$ Square value of 0.181 , which means that the variability of the dependent variable which can be explained by the independent variable is $18.1 \%$, while the remaining $81.9 \%$ is explained by other variables outside the research model.

\section{Wald Test}

This test aims to determine the effect of each independent variable on the dependent variable. Wald test results can be seen in Table 5.4 below.

TABLE IV. LOGISTIC EQUATIONS 1

\begin{tabular}{|c|c|c|c|c|c|c|c|c|}
\hline \multirow[t]{2}{*}{ Variable } & \multirow[t]{2}{*}{ B } & \multirow[t]{2}{*}{ S.E } & \multirow[t]{2}{*}{ Wald } & \multirow[t]{2}{*}{ df } & \multirow[t]{2}{*}{ Sig. } & \multirow[t]{2}{*}{ OR } & \multicolumn{2}{|c|}{ 95\% C.I for EXP (B) } \\
\hline & & & & & & & Lower & Upper \\
\hline Price Products & 0,76 & 0,82 & 0,85 & 1 & 0,35 & 2,14 & 0,42 & 10,78 \\
\hline Product Variations & $-0,24$ & 0,61 & 0,15 & 1 & 0,69 & 0,78 & 0,23 & 2,63 \\
\hline Facility Purchases & 1,94 & 0,85 & 5,21 & 1 & 0,02 & 7,01 & 1,31 & 37,39 \\
\hline Product Quality & $-0,77$ & 0,68 & 1,28 & 1 & 0,25 & 0,46 & 0,12 & 1,75 \\
\hline Social Experience & 1,25 & 0,62 & 3,99 & 1 & 0,04 & 3,49 & 1,02 & 11,94 \\
\hline Constanta & 0,79 & 0,35 & 4,92 & 1 & 0,02 & 2,22 & & \\
\hline
\end{tabular}

The test results individually or partially by using the test Wald as shown in Table 4, obtained two (2) significant variables statistically at the level of $\alpha=5 \%$, namely Ease of Purchase (X3) and Social Experience (X5). Based on the values obtained, the logistic equation model obtained is as follows:

Consumer Preference $=0.798+1.949 \mathrm{KM}+1.252 \mathrm{PS}$
The equation model (5.1) above is not yet the best model because when seen in the table 5.4 in the significance column, there are still 3 (three) variables that do not significantly influence consumer preferences. To get a better model, reprocessing of data is carried out on the variables that significantly affect consumer preferences without including variables that do not have a significant effect. The results of reanalysis of the variables that have significant influence can be seen in Table 5 below:

TABLE V. LOGISTIC EQUATIONS 2

\begin{tabular}{|l|c|c|c|c|c|c|c|c|}
\hline \multicolumn{1}{|c|}{ Variable } & B & S.E & Wald & df & Sig. & OR & \multicolumn{2}{|c|}{$\begin{array}{c}\text { C.I for EXP } \\
\text { (B) }\end{array}$} \\
\cline { 5 - 9 } & & & & & & & Lower & Upper \\
\hline Ease Purchases & 1,50 & 0,66 & 5,08 & 1 & 0,02 & 4,49 & 1,21 & 16,61 \\
\hline Experience Social & 1,16 & 0,60 & 3,67 & 1 & 0,04 & 3,20 & 0,97 & 10,52 \\
Constanta & 0,70 & 0,31 & 5,05 & 1 & 0,02 & 2,02 & & \\
\hline
\end{tabular}


Based on the table it is known that the 2nd significant variable when reprocessed the results are still significant, so the model obtained from the analysis results is as follows:

Consumer Preference $=0.707+1.503 \mathrm{KM}+1.163 \mathrm{PS}$

\section{E. Examination Model}

Examination Model is carried out by testing the entire model (Test G), with the hypothesis:

$$
\text { Нo: } \beta \mathrm{j}=\beta 1=\ldots=\beta p=0
$$

$\mathrm{H} 1$ : there is at least one $\beta \mathrm{j} \# 0$

Based on the results of data processing for testing the logit model as in the following table 6 , it is obtained a value of -2 Log likelihood of i.e., 97.029, then Ho was rejected. This means that the model in equation (4.2) is significant at the significance level with $\alpha=5 \%$, and it can be concluded that all variables can be included in the model. If viewed from the Nagelkerke R Square value of 0.147 , which means that the variability of the dependent variable explained by the variability of the independent variable is $14.7 \%$. its show in Table 6.

TABLE VI. VALUE -2 2ND LIKELIHOOD

\begin{tabular}{|l|c|c|c|}
\hline Step & $\begin{array}{c}-2 \text { Log } \\
\text { likelihood } \\
\text { of }\end{array}$ & $\begin{array}{c}\text { Cox \& Snell R } \\
\text { Square }\end{array}$ & $\begin{array}{c}\text { Nagelkerke R } \\
\text { Square }\end{array}$ \\
\hline 1 & $97.029 \mathrm{a}$ & 0.091 & 0.147 \\
\hline
\end{tabular}

The fit model can be tested with Hosmer and Lemeshow goodness of fit as shown in Table 7 where the hypothesis used 1S:

H0: Empirical data is in accordance with the model

H1: Empirical data does not match the model

The decision-making criteria are:

- If the Hosmer-Lemeshow value $<0.05$ then $\mathrm{H} 0$ is rejected

- If the Hosmer-Lemeshow value is $>0.05$ then $\mathrm{H} 0$ is not rejected.

TABLE VII. HOSMER AND LAMESHOW

\begin{tabular}{|l|l|l|l|}
\hline Step & Chi-square & df & Sig. \\
\hline 1 & 0.796 & 2 & 0.672 \\
\hline
\end{tabular}

In this research model, based on the results of data analysis, it is known that the Hosmer-Lemeshow value is $>0.05$, so H0 is not rejected. This means that the model has fit criteria and empirical data is in accordance with the model.

\section{F. Testing Hypothesis}

Testing uses the Wald test to test each parameter with the following hypotheses:

$$
\begin{aligned}
& \text { Ho: } \beta \mathrm{j}=0 \text { for a certain } \mathrm{j} ; \mathrm{j}=0,1,2, \ldots, \mathrm{p} \\
& \mathrm{H} 1: \beta \mathrm{j} \# 0
\end{aligned}
$$

Where $\mathrm{Ho}$ is rejected if $\mathrm{Wj}>\mathrm{X} 2 \alpha, 1$; where $\alpha$ is the selected significance level. This means that if Ho is rejected, the parameter is statistically significant at the significance level $\alpha$. From the results of data processing as shown in table 5.8, it is found that the test results of Wald each variable have a significance value that is smaller than $\alpha=5 \%$, namely the variable ease of purchase, the test sig value Wald is 0.024 ; and social experience the sig value of the test Wald is 0.043

\section{G. Model Interpretation}

The model of interpretation obtained is carried out by interpreting the coefficients in the logistic regression model in the form of odds ratios (risk comparisons) or in adjusted probability (the probability of occurring) to find out how big the probability of consumer preference choosing a store by considering the results of the equation formation logit follow Table 8:

TABLE VIII. RESULTS ESTABLISHMENT OF EQUATION LOGIT

\begin{tabular}{|l|l|l|}
\hline \multicolumn{1}{|c|}{ Variable } & \multicolumn{1}{|c|}{ Parameters (p value) } & Odds Ratio \\
\hline Intercept & $0.707(0.025)$ & 2.028 \\
\hline $\begin{array}{l}\text { Ease of } \\
\text { purchase }\end{array}$ & $1,503(0,024)$ & 4,497 \\
\hline $\begin{array}{l}\text { experience } \\
\text { Social }\end{array}$ & $1.163(0.043)$ & 3.201 \\
\hline
\end{tabular}

5.1.2.8

Consumer Preference $=0.707+1.503 \mathrm{KM}+1.163 \mathrm{PS}$

\section{H. Interpretation of Intercept}

From the value of the intercept of the equation, which is 0.707 , the probability value of respondents for consumer preference is obtained:

$$
\begin{aligned}
& \text { PK }(p / 1-p)=0.707 \\
& (p / 1-p)=e 0.707 \\
& P=e 0.707 /(1+e 0.707) \\
& P=0.632 \text { or } 63.2 \%
\end{aligned}
$$

This figure shows that the probability of a respondent on purchasing preference is based on the perceived convenience and social experience of choosing an online store compared to an offline store during the Covid-19 pandemic is $63.2 \%$.

\section{Value Interpretation of Slope}

Based on the results of the data analysis above, the slope of each variable is obtained which has the following meanings: 
1) Ease of getting product (ease of purchase): The slope for ease of purchase or ease of getting a product is 1.503 meaning that the opportunity for respondents to easily make purchases in stores online is greater than respondents which is easy to make purchases in stores offline. This can be seen from the value of $\operatorname{Exp}(\mathrm{B})$ or the odds ratio variable of stores online of 4.497 , meaning that the chances of respondents who easily get products in stores online are 4.497 times greater than respondents who easily get products in stores offline.

2) The social experience: Slope for social experience is 1.163 , meaning that the opportunity for respondents based on social experience in online stores is greater than respondents who have experience in stores offline. This can be seen from the value of $\operatorname{Exp}(\mathrm{B})$ or the odds ratio variable of stores online of 3.201, meaning that the opportunity for respondents based on experience in online stores is 3.201 times greater than respondents based on their shopping experience at stores offline.

TABLE IX. LOGIT MOdEL PREDICTION ACCURACY

\begin{tabular}{|c|c|c|c|c|c|}
\hline & \multirow{3}{*}{\multicolumn{2}{|c|}{ Observed }} & \multicolumn{3}{|c|}{ Predicted } \\
\hline & & & \multicolumn{2}{|c|}{$\begin{array}{c}\text { Types of } \\
\text { Consumers }\end{array}$} & \multirow[t]{2}{*}{$\begin{array}{c}\text { Percentage } \\
\text { Correct }\end{array}$} \\
\hline & & & Offline & Online & \\
\hline \multirow{3}{*}{$\begin{array}{l}\text { Step } \\
1\end{array}$} & \multirow{2}{*}{$\begin{array}{l}\text { Types of } \\
\text { Consumer }\end{array}$} & Offline & 3 & 18 & 14.3 \\
\hline & & Online & 3 & 87 & 96.7 \\
\hline & \multicolumn{2}{|c|}{ Overall Percentage } & & & 81.1 \\
\hline
\end{tabular}

Table 9 shows the process for calculating the correct and incorrect estimated value, where in step 1, according to predictions of respondents who choose a shop one, which online, it is 90 people while 87 respondents predict the right means accuracy classification is $96.7 \%$, while for respondents who choose stores offline from 21 people who are rightly classified is 3 people or $14.3 \%$ so that the overall accuracy of this logit model for classification is $81.1 \%$.

\section{DISCUSSION}

\section{A. Consumer Characteristics}

From table 5.1 it can be seen that the majority of consumers are female, namely as many as 86 people, aged between $20-45$ years, as many as 82 people, with undergraduate education level of 59 people, the type of work as a civil servant is as many as 41 people with majority income < Rp. 3,000,000.

\section{B. Factors Affecting Consumer Preferences to Shop at stores Online and Offline Stores During the Covid-19 Pandemic}

Based on individual or partial testing using the test Wald, the factors affecting consumer shopping preferences in store Online and stores offline during the Covid-19 pandemic were easy to get products and social experiences.

1) Effect of ease of getting products on consumer preferences to shop at online stores and stores offline during the covid-19 pandemic: The ease of obtaining products based on a partial test affects consumer preferences for shopping at online and stores offline. This is possible because at this time in the condition of the Covid-19 pandemic which requires people to avoid crowds, so people prefer to shop from home. This is supported by the theory of the ease of getting products, which is that it is not difficult to get goods and services and does not take a long time to get them so that consumers are satisfied [7]. The results of this study are also in line with research conducted which states that the ease of obtaining products is one of the factors for consumers shopping online [10].

2) The influence of social experience on consumer preferences to shop at stores online and stores offline during the covid-19 pandemic: Based on the partial test table, social experiences affect consumer preferences for shopping at online and stores offline. The family is a primary group that plays an important role in the socialization of its members towards product use behavior [9]. This family theory supports the results of this study. This is also in line with the results of research conducted by Sunil with the title "A Comparative Analysis Bricks or Cliks: Consumer Preference" which states that social experience is one of the factors that influence consumer shopping preferences.

\section{Factors Most Dominant Influencing Consumer Shopping}

Based on the test results, the most dominant factor affecting consumer shopping preferences in online and stores offline during the Covid-19 pandemic is the ease of getting products Course this is in accordance with the current pandemic conditions which require people to stay at home so that the convenience factor of making online purchases is the right choice.

\section{Logit Model Accuracy}

Based on the results of the logit model accuracy test as a whole for classification is $81.1 \%$, which means that the accuracy of the logit model is high.

\section{CONCLUSIONS AND SUGGESTIONS}

\section{A. Conclusions}

From the results of the discussion and data analysis that has been carried out in the previous chapters, several conclusions can be made that will answer the research questions, as follows:

- Based on the characteristics of consumers, it is known that the majority of consumers are female, namely as many as 86 people, aged between $20-45$ years, as many as 82 people, with a bachelor's level of education as many as 59 people, type of work as civil servants as many as 41 people with the majority of income $<\mathrm{Rp}$. $3,000,000$ 
- Factors that influence consumer preferences for shopping at stores online and stores offline during the Covid-19 pandemic are the ease of obtaining products and consumer social experiences.

- The most dominant factor affecting consumer preferences for shopping at online stores and stores offline during the Covid-19 pandemic is the ease of getting products. This is evidenced by the value of the ease of obtaining a product coefficient of 1.503 and the odds ratio of 4.497 .

- Based on the regression analysis binary logistic, the opportunity for respondents to choose to shop online is $63.2 \%$. The group of respondents who have the potential to choose online shopping are those who want the convenience of getting goods and services and those who have social experiences.

- The accuracy of this logit model classification is $81.1 \%$.

\section{B. Suggestions}

- It is known from the results of the analysis, the ease of obtaining products is the most dominant factor influencing consumer preferences for shopping at online stores and stores offline during the Covid-19 pandemic, so related to this the researchers suggest easy or access to product sales both in stores offline. and online needs to be improved. Especially in stores online, to continue to improve the quality of the server so that the site does not have errors when accessed by many consumers, add payment methods so that buyers can buy easily, make it easier to cancel product purchases, and so on.
- Further research will be even better if several other variables are added so that the analysis is more complex.

\section{REFERENCES}

[1] M. Fuady, Pengantar Hukum Bisnis, Menata Bisnis Modern di Era Global. Bandung: PT Citra Aditya, 2002.

[2] A. Suryahadi, Ini Perubahan Perilaku Konsumen Indonesia saat Pandemi Corona [Online]. Retrieved from: https://nasional.kontan.co.id/news/iniperubah-perjual-konsumen-indonesia-saat-pandemi-corona, 2020.

[3] https://republika.co.id/berita/q9i1qk383/pembelian-bahan-makananmelalui-emecommerceem-meningkat

[4] P. Kotler and K.L. Keller, Marketing Management (12th ed.). Jakarta: Prehalindo, 2007.

[5] J.M. Munandar, F. Udin and M. Amelia, "Analisis faktor yang mempengaruhi preferensi konsumen produk air minum dalam kemasan di Bogor,’ Jurnal Teknologi Industri Pertanian, vol. 13, no. (3), 2004.

[6] M.P. Groover, Fundamentals of Modern Manufacturing (4th ed.). New Jersey: John Wiley \& Sons, Inc, 2010.

[7] H. Irawan, Prinsip Kepuasan Pelanggan. Jakarta: Elex Media Komputindo, 2002.

[8] K. Armstrong, Marketing an Introducing Prentice Hall (12 ed.) England: Pearson Education, 2017.

[9] T. Suryani, Perilaku Konsumen Implikasi pada Strategi Pemasaran (1 ed.) Yogyakarta: Elex Media Komputindo, 2008.

[10] D.A. Harahap, "Perilaku belanja online di Indonesia: Studi kasus," JRMSI-Jurnal Riset Manajemen Sains Indonesia, vol. 9, no. (2), pp. 193213, 2018.

[11] S.P.A.C.E. Sunil, "Bricks or clicks: consumer preference-a comparative analysis," International Journal of Marketing \& Business Communication, vol. 2, no. (3), pp. 1-13, 2013.

[12] D. Wibisono, Panduan Penyusunan Skripsi, Tesis, \& Disertasi. Yogyakarta: ANDI, 2013. 